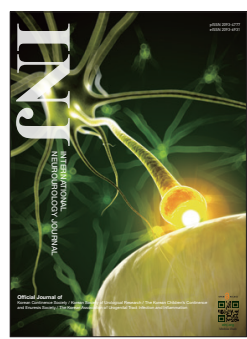

\title{
Stem Cell Therapy for Neurogenic Bladder After Spinal Cord Injury: Clinically Possible?
}

\author{
Su Jin Kim ${ }^{1}$, Young Sam $\mathrm{Cho}^{2}$, Jong Mok Park ${ }^{3}$, Young Gil Na ${ }^{3}$, Khae Hawn Kim ${ }^{4}$ \\ ${ }^{1}$ Department of Urology, Yonsei University Wonju College of Medicine, Wonju, Korea \\ ${ }^{2}$ Department of Urology, Sungkyunkwan University School of Medicine, Seoul, Korea \\ ${ }^{3}$ Department of Urology, Chungnam National University Sejong Hospital, Chungnam National University College of Medicine, Sejong, Korea \\ ${ }^{4}$ Department of Urology, Gachon University Gil Medical Center, Gachon University of School of Medicine, Incheon, Korea
}

\begin{abstract}
Neurogenic bladder (NB) after spinal cord injury (SCI) is a common complication that inhibits normal daily activities and reduces the quality of life. Regrettably, the current therapeutic methods for NB are inadequate. Therefore, numerous studies have been conducted to develop new treatments for NB associated with SCI. Moreover, a myriad of preclinical and clinical trials on the effects and safety of stem cell therapy in patients with SCI have been performed, and several studies have demonstrated improvements in urodynamic parameters, as well as in sensory and motor function, after stem cell therapy. These results are promising; however, further high-quality clinical studies are necessary to compensate for a lack of randomized trials, the modest number of participants, variation in the types of stem cells used, and inconsistency in routes of administration.
\end{abstract}

Keywords: Urinary bladder; Neurogenic; Spinal cord injury; Stem cells, Clinical trials

- Fund/Grant Support: This research was supported by Basic Science Research Program through the National Research Foundation of Korea (NRF) funded by the Ministry of Education (2018R1D1A3B07048492).

- Conflict of Interest: SJK, YSC, and KHK, members of the Editorial Board of International Neurourology Journal, are the authors of this article. However, they played no role whatsoever in the editorial evaluation of this article or the decision to publish it. Except for that, no potential conflict of interest relevant to this article was reported.

\section{INTRODUCTION}

Regenerative medicine provides a valuable therapeutic framework for remedying remedy difficult-to-treat diseases and impaired tissue. The term "regenerative medicine" was first used by Kaiser in 1992 [1]. Cell-based therapy and tissue engineering are the two most significant components of regenerative medicine, and each of them can be applied independently or in combination to generate synergistic effects [2]. In the history of regenerative medicine in urology, Atala et al. [3,4] showed promising results by implanting a tissue-engineered bladder and ure- thra using autologous cells and scaffolds in humans for the first time. Since then, extensive research has investigated the possibility of using stem cells for therapeutic purposes in various difficult-to-treat urologic diseases such as incontinence, neurogenic bladder (NB), erectile dysfunction, and interstitial cystitis/bladder pain syndrome [5].

Stem cell therapy has been invaluable in the treatment of numerous serious diseases that cannot be adequately treated with existing therapeutic modalities. Therefore, NB associated with central nervous injury or dysfunction is an optimal candidate for stem cell therapy because it is challenging to promote the

Corresponding author: Khae Hawn Kim (iD https://orcid.org/0000-0002-7045-8004 Department of Urology, Gachon University School of Medicine, Gil Medical Center, 21 Namdong-daero 774 beon-gil, Namdong-gu, Incheon 21565, Korea E-mail: kimcho99@gilhospital.com / Tel: +82-32-460-3334 / Fax: +82-32-460-8340 Submitted: April 1, 2020 / Accepted after revision: May 9, 2020 
recovery of injuries or degenerative changes in the central nervous system [6-8]. Disability induced by spinal cord injury (SCI) is a serious problem that impacts quality of life, and its prevalence is noteworthy, although the exact incidence has not been determined. In aging societies, falls are common among elderly individuals, which has contributed to an increasing incidence of SCI $[9,10]$. One of the most common problems in SCI patients is NB; however, the current medical and surgical treatment of NB focuses only on modulating the function of the bladder, not on promoting recovery of the SCI [11,12]. In addition, the therapeutic outcome of NB treatment is generally insufficient because the SCI is often permanent. Thus, neuronal regeneration using stem cell therapy may contribute to the restoration of functional impairment after SCI.

\section{MECHANISM OF STEM CELL THERAPY IN NEURAL REGENERATION AFTER SPINAL CORD INJURY}

At present, the Wnt/ $\beta$-catenin signaling pathway, the Rho/Rock signaling pathway, the Notch signaling pathway, and the JAKSTAT3 signaling pathway have been considered as possible signaling pathways associated with neural regeneration after stem cell therapy. After SCI activation of the Wnt/ $\beta$-catenin signaling pathway promotes neural regeneration, while the Rho/Rock signaling pathway, the Notch signaling pathway, and the JAKSTAT3 signaling pathway inhibit neural regeneration. The Wnt/ $\beta$-catenin signaling pathway contributes to the development of the nervous system and is activated in the early period after SCI and subsequently decreases with time. Wnt expression increases rapidly in the acute phase of SCI. Therefore, increased expression of Wnt plays a role in recruiting endogenous neural stem cells and in restoring damaged neural tissue [13-20]. Thus, up- or down-regulation of these signaling pathways influences the neural differentiation of stem cells.

To improve the role of stem cells in repairing damaged tissue, the microenvironmental balance around stem cells is also important. The extracellular matrix (ECM), cytokines, and tissuespecific cells modulate the microenvironment, and an imbalance of these components inhibits neural regeneration. The ECM is a 3-dimensional network that shapes the central nervous system, and breakdown of the ECM after SCI influences neuronal and nonneuronal cell migration, communication, and survival, which are important for recovery from SCI. Therefore, ensuring an adequate ECM for the damaged spinal cord is a therapeutic approach that aims to provide a proper environment for repair after SCI [21]. Several studies have shown a synergistic effect after combined treatment with biocompatible scaffolds and stem cells [22-24]. Moreover, the paracrine effect of stem cells promotes neural regeneration by regulating neurotrophic factors, cytokines, and chemokines [25].

\section{PRECLINICAL STEM CELL THERAPY FOR THE TREATMENT OF SPINAL CORD INJURY}

Multiple preclinical studies have investigated the use of various types of stem cells after SCI, evaluating the roles of mesenchymal stem cells (MSCs), induced pluripotent stem cells (iPSCs), and neural stem cells in morphological and functional recovery after SCI. Many studies have investigated stem cell therapy with MSC have been performed because MSCs because MSCs have considerable potential for differentiation and anti-inflammatory and immunomodulatory properties [26]. MSCs can be isolated from various tissues, such as the bone marrow, umbilical cord, adipose tissue, and oral mucosa. All types of MSCs have been shown to lead to neural regeneration in a SCI animal model induced by spinal cord transection and contusion. Moreover, therapeutic effects of MSCs have been observed in both the acute and chronic phases after SCI. Regarding the route of administration, direct injection to the injured area and intravenous or intrathecal administration of MSCs have led to improved neural regeneration [27-32]. Bone marrow mesenchymal stem cells (BM-MSC) is low immunogenicity compared with MSCs from other tissue. However, considerable pain that occurs during the process of obtaining BM-MSC from bone marrow is an issue. In contrast, adipose-derived stem cells (ADSCs) have the advantage of being readily obtainable from adipose tissue. Therefore, the patient experiences less pain than when BM-MSCs are used.

Many studies have investigated the use of iPSCs because iPSCs derived from autologous somatic cells have similar characteristics to embryonic stem cells, therevy circumventing ethical issues [33]. Several studies have shown autologous iPSC-derived neural precursor cells exerted effects on neural regeneration through remyelination after SCI [34-36]. However, iPSCs have a higher rate of tumorigenicity due to the epigenetic memory of the original somatic cells and reprogramming. Neural stem cells are obtained from the brain (lateral ventricle, dentate gyrus of the hippocampus) and the central canal of the spinal cord. Neural stem cells can differentiate into neurons, as- 
Table 1. Completed clinical trials that reported results (http://clinicaltrials.gov/)

\begin{tabular}{|c|c|c|c|c|c|c|c|c|}
\hline Identifier & $\begin{array}{c}\text { Clinical trial } \\
\text { phase }\end{array}$ & $\begin{array}{c}\text { Type of } \\
\text { SCI }\end{array}$ & $\begin{array}{c}\text { No. of } \\
\text { patients }\end{array}$ & $\begin{array}{c}\text { Age (yr), } \\
\text { range }\end{array}$ & Cell type & $\begin{array}{l}\text { Delivery } \\
\text { method }\end{array}$ & Efficacy & Safety \\
\hline $\begin{array}{l}\text { NCT01325103 } \\
\text { [39] }\end{array}$ & Phase 1 & $\begin{array}{l}\text { Thoracic or } \\
\text { lumbar } \\
\text { traumatic SCI } \\
\text { (ASIA } \\
\text { grade A) }\end{array}$ & 14 & $18-65$ & $\begin{array}{l}\text { Autologous } \\
\text { BM-MSC }\end{array}$ & $\begin{array}{l}\text { Intralesional } \\
\text { injection after } \\
\text { laminectomy and } \\
\text { decompression of } \\
\text { the spinal lesion } \\
\text { area }\end{array}$ & $\begin{array}{l}\text { Variably enhanced } \\
\text { sensitivity below } \\
\text { the injury area was } \\
\text { observed. } \\
8 \text { patients: } \\
\text { improvement of } \\
\text { lower limb motor } \\
\text { function, } \\
7 \text { patients: } \\
\text { improvement of } \\
\text { AIS, } 3 \text { patients: im- } \\
\text { provement of neu- } \\
\text { ropathic pain }\end{array}$ & $\begin{array}{l}\text { 14 Patients: } \\
\text { discharge within } \\
48 \text { hours after } \\
\text { surgery, 1: } \\
\text { cerebrospinal } \\
\text { leak related to } \\
\text { surgery, } \\
\text { no severe } \\
\text { adverse events }\end{array}$ \\
\hline $\begin{array}{l}\text { NCT02482194 } \\
\text { [40] }\end{array}$ & Phase 1 & $\begin{array}{l}\text { Chronic and } \\
\text { subacute SCI }\end{array}$ & 9 & $18-50$ & $\begin{array}{l}\text { Autologous } \\
\text { BM-MSCs }\end{array}$ & $\begin{array}{l}\text { Intrathecal } \\
\text { injection }\end{array}$ & $\begin{array}{l}\text { At } 1 \text { year after } \\
\text { treatment, no } \\
\text { alteration in the } \\
\text { hyperintense } \\
\text { signal and no } \\
\text { formation of } \\
\text { ectopic tissue }\end{array}$ & $\begin{array}{l}\text { No severe adverse } \\
\text { event, } 1 \text { patient: } \\
\text { severe headache, } \\
2 \text { patients: } \\
\text { nonspecific } \\
\text { tingling } \\
\text { sensation }\end{array}$ \\
\hline NCT01909154 & Phase 1 & $\begin{array}{l}\text { Chronic } \\
\text { paraplegia } \\
\text { (ASIA } \\
\text { grade A) }\end{array}$ & 9 & $18-50$ & $\begin{array}{l}\text { Autologous } \\
\text { BM-MSCs }\end{array}$ & $\begin{array}{l}\text { Intrathecal } \\
\text { injection (second } \\
\text { injection at } 3 \\
\text { months after the } \\
\text { first injection) }\end{array}$ & $\begin{array}{l}\text { Sensory recovery, } \\
\text { improvement of } \\
\text { chronic pain, } \\
\text { presence of SSEPs }\end{array}$ & $\begin{array}{l}\text { No severe adverse } \\
\text { events, nausea, } \\
\text { urinary tract } \\
\text { infection, back } \\
\text { pain, thoracic } \\
\text { pain, muscle } \\
\text { contracture, } \\
\text { myalgia, } \\
\text { headache }\end{array}$ \\
\hline $\begin{array}{l}\text { NCT00816803 } \\
{[41]}\end{array}$ & Phase1/2 & $\begin{array}{l}\text { Chromic SCI } \\
\text { with thoracic } \\
\text { spinal trauma }\end{array}$ & 70 & $10-36$ & $\begin{array}{l}\text { Autologous } \\
\text { BM-MSCs with } \\
\text { physiotherapy } \\
(\mathrm{n}=50) \\
\text { standard } \\
\text { rehabilitative } \\
\text { therapy with } \\
\text { physiotherapy } \\
(\mathrm{n}=20)\end{array}$ & $\begin{array}{l}\text { Intrathecal } \\
\text { injection }\end{array}$ & $\begin{array}{l}\text { Autologous BM- } \\
\text { MSCs with } \\
\text { physiotherapy } \\
\text { group: } 17 \text { patients } \\
\text { showed } \\
\text { improvement of } \\
\text { the ASIA score, } 23 \\
\text { patients showed } \\
\text { improvement of } \\
\text { motor function }\end{array}$ & $\begin{array}{l}\text { Headaches, } \\
\text { mild pain }\end{array}$ \\
\hline $\begin{array}{l}\text { NCT01274975 } \\
{[42]}\end{array}$ & Phase 1 & $\begin{array}{l}\text { Traumatic SCI } \\
\text { (ASIA } \\
\text { grade A or B) }\end{array}$ & 8 & $19-60$ & $\begin{array}{l}\text { Autologous } \\
\text { ADSCs }\end{array}$ & $\begin{array}{l}\text { Intravenous } \\
\text { infusion }\end{array}$ & $\begin{array}{l}\text { MRI at } 12 \text { weeks } \\
\text { after therapy } \\
\text { showed a } \\
\text { reduction of } \\
\text { injured lesions } \\
\text { without } \\
\text { significance. } \\
\text { Conversion from } \\
\text { ASIA A to ASIA C } \\
\text { and improvement } \\
\text { of motor and } \\
\text { sensory function } \\
\text { were noted in } 1 \\
\text { patient }\end{array}$ & $\begin{array}{l}\text { No severe } \\
\text { adverse } \\
\text { events }\end{array}$ \\
\hline $\begin{array}{l}\text { NCT01393977 } \\
{[43]}\end{array}$ & Phase 3 & $\begin{array}{l}\text { Thoracolumbar } \\
\text { SCI }\end{array}$ & 34 & $20-50$ & $\begin{array}{l}\text { UC-MSC } \\
\text { transplantation } \\
\text { group, } \\
\text { rehabilitation } \\
\text { therapy group, } \\
\text { control group }\end{array}$ & $\begin{array}{l}\text { Intrathecal } \\
\text { injection }\end{array}$ & $\begin{array}{l}\text { Seven of } 10 \text { patients } \\
\text { treated with UC- } \\
\text { MSCs showed } \\
\text { significant } \\
\text { improvement of } \\
\text { motor function }\end{array}$ & $\begin{array}{l}\text { Radiating } \\
\text { neuralgia after } \\
\text { UC-MSC } \\
\text { transplantation; } \\
\text { improvement } \\
\text { within } 24 \text { hours }\end{array}$ \\
\hline
\end{tabular}

SCI, spinal cord injury; ASIA, American Spinal Injury Association; BM-MSCs, bone marrow stem cells; AIS, Association Impairment Scale; SSEP, somatosensory evoked potential; ADSCs, adipose-derived mesenchymal stem cells; MRI, magnetic resonance imaging; UC-MSCs, umbilical cord mesenchymal stem cells. 
trocytes, and oligodendrocytes in the nervous system [37]. Previous studies of neural stem cells showed axonal regeneration at the injured area and functional recovery [38].

\section{CLINICAL TRIALS OF STEM CELL THERAPY AFTER SPINAL CORD INJURY}

A considerable number of clinical trials that have evaluated the effects and safety of stem cell therapy in SCI patients on the basis of preclinical research. Therefore, a review of clinical trials registered on ClinicalTrials.gov was performed to evaluate the outcomes of stem cell therapy in SCI patients. In total, 30 clinical trials were identified (complete: $n=18$ and ongoing: $n=12$ ), excluding withdrawn and terminated studies. Six of the 18 completed studies reported the results of the trials (Table 1). The completed clinical trials were phase 1 or 2 studies, and types of stem cells were autologous BM-MSCs, autologous ADSCs, and umbilical cord mesenchymal stem cells (UC-MSCs) [39-43]. There was only one phase 3 clinical trial, which compared a stem cell transplantation group, a rehabilitation group, and a blank control group [43]. The route of administration was injection the injured area, intrathecal injection, and intravenous infusion. Three studies performed stem cell therapy together with other treatments, such as decompression of the spinal lesion; physiotherapy involving mat activities, strengthening exercises, self-range of motion, ambulation training for paraplegic patients, and cardiopulmonary training; and rehabilitation therapy $[39,41,43]$.

The baseline severity of SCI was classified according to the American Spinal Injury Association (ASIA) impairment score. After stem cell treatment, sensory and motor function was evaluated with the ASIA impairment score, the Association Impairment Scale score, and somatosensory evoked potentials. Some studies used computed tomography and magnetic resonance imaging of the spinal cord to assess structural changes after stem cell treatment. The 6 studies that reported results showed improvements in sensory and motor function, regardless of the types of stem cells and administration route. A combination of stem cell therapy with physiotherapy and rehabilitation therapy showed remarkable improvements in motor function compared with the patients treated with physiotherapy and rehabilitation therapy only. In addition, no severe adverse events were observed in any studies, and only mild and transient adverse events such as headache, low-level pain, and nonspecific tingling sensations were reported.

\section{PRECLINICAL STEM CELL THERAPY FOR THE TREATMENT OF NEUROGENIC BLADDER AFTER SPINAL CORD INJURY}

NB is a commonly observed functional impairment after SCI, and several animal studies have evaluated the effects of stem cell therapy on bladder function. Previous studies used various SCI animal models to represent NB in SCI patients, and SCI was induced by contusion, transection, and needle-stick injury of the spinal cord [44-50]. Five different sources were used: BM-MSCs, human UC-MSCs, neuronal stem cells, human MSCs, and oral mucosa stem cells. Most of the studies administered stem cells through direct injection to the injured area between 3 days and 13 weeks after the injury. Bladder function was evaluated by performing a urodynamic study (UDS) after stem cell therapy. Compared with the SCI group without treatment, the stem cell therapy group showed decreased voiding pressure and non-voiding contraction and increased bladder compliance and bladder capacity. In addition to UDS, some previous studies simultaneously evaluated sensory and motor function. Functional changes after stem cell therapy varied from minimal to a significant improvement.

\section{CLINICAL TRIALS OF STEM CELL THERAPY FOR NEUROGENIC BLADDER AFTER SPINAL CORD INJURY}

There were 10 clinical trials of stem cell therapy for NB after SCI that included evaluations of bladder function. Among them, 5 studies were completed, and 5 studies were ongoing (Table 2). All of them except 1 study (phase 3) [43] were phase 1 or 2 clinical trials, and they used stem cells such as autologous BM-MSCs, UC-MSCs, Wharton's jelly MSCs, and human-spinal cord-derived neural stem cells. The administration route in most of these studies was intrathecal injection. In 1 study (NCT01909154; see Table 1), a second injection was performed 3 months after the first injection. Bladder function was evaluated with UDS in the completed clinical trials except for 1 study (NCT02570932). Increased maximum cytometric capacity, improved compliance, and decreased detrusor pressure were noted, with results comparable to those of preclinical studies. However, these improvements of UDS did not reduce urinary incontinence or eliminate the need for clean intermittent catheterization (CIC). Five ongoing clinical trials are planning to evaluate bladder function with UDS, measurements of postvoid 


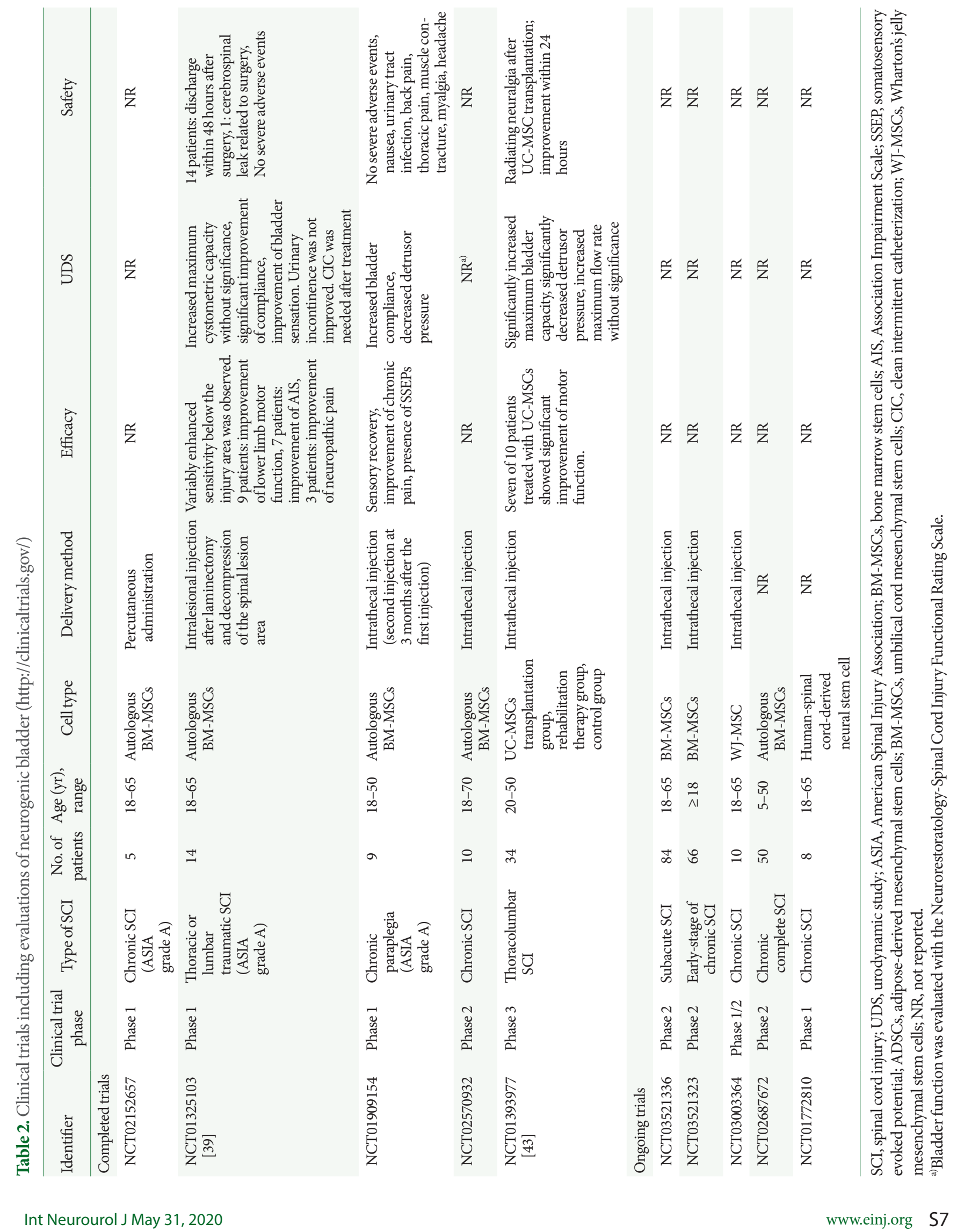


residual urine volume, and data obtained via questionnaires.

\section{WHAT IS NECESSARY FOR CLINICAL APPLICATIONS?}

Increasingly many preclinical and clinical studies have investigated the effects of stem cell therapy on NB related to SCI, and several positive results have been reported in previous clinical trials. However, many questions remain about the effects and safety of stem cell therapy. Most of the previous clinical trials were not randomized trials, did not have a control group, and included a small number of patients. Moreover, the dose, route of administration, and timing were different in each of the studies. Furthermore, no studies demonstrated functional recovery of voiding; as mentioned above, patients still had persistent urinary incontinence and a continuing need for CIC. Furthermore, no study showed improvements in sensory and motor function after stem cell therapy. Therefore, further studies are necessary to demonstrate clear evidence regarding stem cell therapy and the appropriate direction for standardization of therapeutic methods. Moreover, the Tissue Engineering \& Regenerative Medicine International Society (TERMIS) suggested 5 significant drivers for the translation of regenerative medicine, including stem cell therapy, to real clinical practice [51]. The major drivers pointed out by TERMIS are: fully validated manufacturing capability for stem cells, reimbursement for NB related to SCI, regulation of the design and development of stem cells that will show consistent effect and safety, collaboration among various researchers and economic actors, and clinical development plans to reduce the risk of failure.

\section{CONCLUSIONS}

Stem cell therapy is a promising therapeutic option for NB related to SCI, and many preclinical and clinical studies have been conducted to demonstrate the efficacy and safety of stem cell therapy. Several clinical trials have demonstrated improvements in bladder function. However, clear evidence is lacking because most of the extant clinical trials were not high-quality, and therapeutic methods varied among the studies. Therefore, there is a pressing need for further studies to demonstrate evidence of the therapeutic potential of stem cell therapy and to enable the translation of stem cell therapy to real-world practice.

\section{AUTHOR CONTRIBUTION STATEMENT}

- Conceptualization: $S J K$

- Formal Analysis: YSC

- Investigation: SJK, YSC

- Methodology: SJK, YSC, JMP

- Project Administration: $K H K$

- Writing - Original Draft: SJK

- Writing - Review \& Editing: KHK, YGN

\section{REFERENCES}

1. Kaiser LR. The future of multihospital systems. Top Health Care Financ 1992;18:32-45.

2. Mason C, Dunnill P. A brief definition of regenerative medicine. Regen Med 2008;3:1-5.

3. Atala A, Bauer SB, Soker S, Yoo JJ, Retik AB. Tissue-engineered autologous bladders for patients needing cystoplasty. Lancet 2006;367: 1241-6.

4. Raya-Rivera A, Esquiliano DR, Yoo JJ, Lopez-Bayghen E, Soker S, Atala A. Tissue-engineered autologous urethras for patients who need reconstruction: an observational study. Lancet 2011;377:117582.

5. Panda A. Stem cell in urology-are we at the cusp of a new era? Transl Androl Urol 2018;7:653-8.

6. Chen ZL, Yu WM, Strickland S. Peripheral regeneration. Annu Rev Neurosci 2007;30:209-33.

7. Burnett MG, Zager EL. Pathophysiology of peripheral nerve injury: a brief review. Neurosurg Focus 2004;16:E1.

8. Ide C. Peripheral nerve regeneration. Neurosci Res 1996;25:101-21.

9. Khan A, Pujol C, Laylor M, Unic N, Pakosh M, Dawe J, et al. Falls after spinal cord injury: a systematic review and meta-analysis of incidence proportion and contributing factors. Spinal Cord 2019;57:52639.

10. Hamid R, Averbeck MA, Chiang H, Garcia A, Al Mousa RT, Oh SJ, et al. Epidemiology and pathophysiology of neurogenic bladder after spinal cord injury. World J Urol 2018;36:1517-27.

11. Romo PGB, Smith CP, Cox A, Averbeck MA, Dowling C, Beckford $\mathrm{C}$, et al. Non-surgical urologic management of neurogenic bladder after spinal cord injury. World J Urol 2018;36:1555-68.

12. Roth JD, Cain MP. Neuropathic bladder and augmentation cystoplasty. Urol Clin North Am 2018;45:571-85.

13. Willert K, Nusse R. Wnt proteins. Cold Spring Harb Perspect Biol 2012;4:a007864.

14. Gonzalez-Fernandez C, Arevalo-Martin A, Paniagua-Torija B, Ferrer 
I, Rodriguez FJ, Garcia-Ovejero D. Wnts are expressed in the ependymal region of the adult spinal cord. Mol Neurobiol 2017;54:6342-55.

15. Gao J, Liao Y, Qiu M, Shen W. Wnt/ $\beta$-catenin signaling in neural stem cell homeostasis and neurological diseases. Neuroscientist 2020: 1073858420914509. https://doi.org/10.1177/1073858420914509 [Epub].

16. Liu J, Gao HY, Wang XF. The role of the Rho/ROCK signaling pathway in inhibiting axonal regeneration in the central nervous system. Neural Regen Res 2015;10:1892-6.

17. Gu H, Yu SP, Gutekunst CA, Gross RE, Wei L. Inhibition of the Rho signaling pathway improves neurite outgrowth and neuronal differentiation of mouse neural stem cells. Int J Physiol Pathophysiol Pharmacol 2013;5:11-20.

18. Chen Y, Lian XH, Liao LY, Liu YT, Liu SL, Gao Q. Transplantation of bone marrow mesenchymal stem cells alleviates spinal cord injury via inhibiting Notch signaling. Eur Rev Med Pharmacol Sci 2019;23(3 Suppl):31-8.

19. Zhang S, Botchway BOA, Zhang Y, Liu X. Resveratrol can inhibit Notch signaling pathway to improve spinal cord injury. Ann Anat 2019;223:100-7.

20. Dominguez E, Rivat C, Pommier B, Mauborgne A, Pohl M. JAK/ STAT3 pathway is activated in spinal cord microglia after peripheral nerve injury and contributes to neuropathic pain development in rat. J Neurochem 2008;107:50-60.

21. Gaudet AD, Popovich PG. Extracellular matrix regulation of inflammation in the healthy and injured spinal cord. Exp Neurol 2014;258:24-34.

22. Han IB, Thakor DK, Ropper AE, Yu D, Wang L, Kabatas S, et al. Physical impacts of PLGA scaffolding on hMSCs: recovery neurobiology insight for implant design to treat spinal cord injury. Exp Neurol 2019;320:112980.

23. Fan C, Li X, Xiao Z, Zhao Y, Liang H, Wang B, et al. A modified collagen scaffold facilitates endogenous neurogenesis for acute spinal cord injury repair. Acta Biomater 2017;51:304-16.

24. Shrestha B, Coykendall K, Li Y, Moon A, Priyadarshani P, Yao L. Repair of injured spinal cord using biomaterial scaffolds and stem cells. Stem Cell Res Ther 2014;5:91.

25. Mukhamedshina YO, Gracheva OA, Mukhutdinova DM, Chelyshev YA, Rizvanov AA. Mesenchymal stem cells and the neuronal microenvironment in the area of spinal cord injury. Neural Regen Res 2019;14:227-37.

26. Pittenger MF, Discher DE, Péault BM, Phinney DG, Hare JM, Caplan AI. Mesenchymal stem cell perspective: cell biology to clinical progress. NPJ Regen Med 2019;4:22.

27. Deng YB, Liu XG, Liu ZG, Liu XL, Liu Y, Zhou GQ. Implantation of BM mesenchymal stem cells into injured spinal cord elicits de novo neurogenesis and functional recovery: evidence from a study in rhesus monkeys. Cytotherapy 2006;8:210-4.

28. Zurita M, Vaquero J, Bonilla C, Santos M, De Haro J, Oya S, et al. Functional recovery of chronic paraplegic pigs after autologous transplantation of bone marrow stromal cells. Transplantation 2008;86:845-53.

29. Pal R, Gopinath C, Rao NM, Banerjee P, Krishnamoorthy V, Venkataramana NK, et al. Functional recovery after transplantation of bone marrow-derived human mesenchymal stromal cells in a rat model of spinal cord injury. Cytotherapy 2010;12:792-806.

30. Kim Y, Lee SH, Kim WH, Kweon OK. Transplantation of adipose derived mesenchymal stem cells for acute thoracolumbar disc disease with no deep pain perception in dogs. J Vet Sci 2016;17:123-6.

31. Ohta Y, Hamaguchi A, Ootaki M, Watanabe M, Takeba Y, Iiri T, et al. Intravenous infusion of adipose-derived stem/stromal cells improves functional recovery of rats with spinal cord injury. Cytotherapy 2017;19:839-48.

32. Ganz J, Shor E, Guo S, Sheinin A, Arie I, Michaelevski I, et al. Implantation of $3 \mathrm{D}$ constructs embedded with oral mucosa-derived cells induces functional recovery in rats with complete spinal cord transection. Front Neurosci 2017;11:589.

33. Yamanaka S. Induced pluripotent stem cells: past, present, and future. Cell Stem Cell 2012;10:678-84.

34. Salewski RP, Mitchell RA, Li L, Shen C, Milekovskaia M, Nagy A, et al. Transplantation of induced pluripotent stem cell-derived neural stem cells mediate functional recovery following thoracic spinal cord injury through remyelination of axons. Stem Cells Transl Med 2015;4:743-54.

35. Fujimoto Y, Abematsu M, Falk A, Tsujimura K, Sanosaka T, Juliandi B, et al. Treatment of a mouse model of spinal cord injury by transplantation of human induced pluripotent stem cell-derived long-term self-renewing neuroepithelial-like stem cells. Stem Cells 2012;30:1163-73.

36. Nagoshi N, Okano H. Applications of induced pluripotent stem cell technologies in spinal cord injury. J Neurochem 2017;141:84860.

37. Nam H, Lee KH, Nam DH, Joo KM. Adult human neural stem cell therapeutics: current developmental status and prospect. World J Stem Cells 2015;7:126-36.

38. Pereira IM, Marote A, Salgado AJ, Silva NA. Filling the gap: neural stem cells as a promising therapy for spinal cord injury. Pharmaceuticals (Basel) 2019;12:2.

39. Mendonça MV, Larocca TF, de Freitas Souza BS, Villarreal CF, Silva LF, Matos AC, et al. Safety and neurological assessments after au- 
tologous transplantation of bone marrow mesenchymal stem cells in subjects with chronic spinal cord injury. Stem Cell Res Ther 2014;5:126.

40. Satti HS, Waheed A, Ahmed P, Ahmed K, Akram Z, Aziz T, et al. Autologous mesenchymal stromal cell transplantation for spinal cord injury: a phase I pilot study. Cytotherapy 2016;18:518-22.

41. El-Kheir WA, Gabr H, Awad MR, Ghannam O, Barakat Y, Farghali $\mathrm{HA}$, et al. Autologous bone marrow-derived cell therapy combined with physical therapy induces functional improvement in chronic spinal cord injury patients. Cell Transplant 2014;23:729-45.

42. Ra JC, Shin IS, Kim SH, Kang SK, Kang BC, Lee HY, et al. Safety of intravenous infusion of human adipose tissue-derived mesenchymal stem cells in animals and humans. Stem Cells Dev 2011;20:1297-308.

43. Cheng H, Liu X, Hua R, Dai G, Wang X, Gao J, et al. Clinical observation of umbilical cord mesenchymal stem cell transplantation in treatment for sequelae of thoracolumbar spinal cord injury. J Transl Med 2014;12:253.

44. Sandner B, Ciatipis M, Motsch M, Soljanik I, Weidner N, Blesch A. Limited functional effects of subacute syngeneic bone marrow stromal cell transplantation after rat spinal cord contusion injury. Cell Transplant 2016;25:125-39.

45. Hu Y, Liao LM, Ju YH, Fu G, Zhang HY, Wu HX. Intravenously transplanted bone marrow stromal cells promote recovery of lower urinary tract function in rats with complete spinal cord injury. Spinal Cord 201250:202-7.

46. Erdogan B, Yaycioglu O, Feride Sahin I, Kayaselcuk F, Cemil B, Cemal Gokce E, et al. The effects of fetal allogeneic umbilical cord tissue transplant following experimental spinal cord injury on urinary bladder morphology. Neurol Neurochir Pol 2013;47:138-44.

47. Mitsui T, Kakizaki H, Tanaka H, Shibata T, Matsuoka I, Koyanagi T. Immortalized neural stem cells transplanted into the injured spinal cord promote recovery of voiding function in the rat. J Urol 2003; 170:1421-5.

48. Jin Y, Bouyer J, Shumsky JS, Haas C, Fischer I. Transplantation of neural progenitor cells in chronic spinal cord injury. Neuroscience 2016;320:69-82.

49. Park WB, Kim SY, Lee SH, Kim HW, Park JS, Hyun JK. The effect of mesenchymal stem cell transplantation on the recovery of bladder and hindlimb function after spinal cord contusion in rats. BMC Neurosci 2010;11:119.

50. Cho YS, Ko IG, Kim SE, Lee SM, Shin MS, Kim CJ, et al. Oral mucosa stem cells alleviates spinal cord injury-induced neurogenic bladder symptoms in rats. J Biomed Sci 2014;21:43.

51. Ronfard V, Vertès AA, May MH, Dupraz A, van Dyke ME, Bayon Y. Evaluating the past, present, and future of regenerative medicine: a global view. Tissue Eng Part B Rev 2017;23:199-210. 